\title{
Enforcing Building Set Backs as a Viable Strategy for an Emerging City
}

\author{
Abdulazeez Umar Raji ${ }^{1}$, Umar Ahmed Attah ${ }^{1}$ \\ ${ }^{1}$ Modibbo Adama University of Technology Yola \\ P. M. B. 2076, Yola Adamawa State, Nigeria
}

DOI: $10.22178 /$ pos.23-2

LCC Subject Category: TH845-895

Received 18.05.2017

Accepted 15.06.2017

Published online 19.06.2017

Corresponding Author:

Abdulazeez U. Raji,

abdulazeezraji@hotmail.com

(C) 2017 The Authors. This article is

licensed under a Creative Commons

Attribution 4.0 License @) (1)

\begin{abstract}
For any emerging city to grow into a healthy and safe city, development guidelines and regulations which serve as a vital strategy should be considered and be adhered to. Most importantly the town and country planning laws which are purposely designed to regulate various development aspects that includes, zoning practices, occupancy type building height, as well as building setbacks among many other regulations, depending on the problems of a particular locality. Suleja in the last three decades has rapidly experienced increase in size with numerous number of buildings springing up, largely as a result of its proximity to the new Federal Capital Territory; unfortunately most of the buildings were haphazardly placed with less or little regard to local planning regulations. This paper is aimed to explore how non adherence to building setbacks affects the immediate dwelling units of an area. A field survey and oral interviews were used in three core areas of Suleja to evaluate the level of nonadherence of building setbacks, and its resultant effects. The research findings identified several problems arising from non-compliance to building setbacks regulations, which includes poorly lightened and ventilated interiors of dwelling units, lack of access roads linking buildings with main roads, lack of outdoor spaces for parking vehicles and unsafe environment which all leads to a poor city growth.
\end{abstract}

Keywords: building setbacks; building regulations; congestion; emerging city; planning authorities.

\section{Introduction}

Land use regulations such as building setbacks are one of the principal techniques employed to achieve a good urban development. Great cities in the world today had only attained their greatness through a series of coordination in their development stages. G. Nwaka mentioned that these regulations are conducted principally at the local level and depend largely on the land use district where a building is located [6]. Z. Samadi and M. Hasbullah defines building setbacks as the left over spaces mostly found in between buildings in front, at the sides and at the rear of buildings which varies in size and location [9]. This definition is mainly dwelling on the micro planning level which mainly concerns the architect, whereas the city of Belleview land use document defines building set back as a space in which no structure as define by land use may be located except where specifically allowed by the land use code, the document further stated that setbacks are required along front rear and side property lines and some easements.

The provision of setbacks has a positive influence on the design of buildings and promotes good health and welfare, through the provision of functional and adequate outdoor spaces and also well lightened and ventilated building interiors. It provides access, skyline views and recreational uses such as outdoor dining, gardening, and children play. It further promotes fire safety by spacing building and their protruding parts away from each other and allows passage of fire fighting apparatus between buildings. Z. Samadi and M. Hasbullah argued that street furniture, skyline 
views, spaces between buildings, architectural style height and sizes of facades, creates positive city image [9].

The concept of building setbacks originated in New York 1916, and was authored by Edward Bassett while serving on the blue ribbon U.S commerce advisory committee whom were assigned the responsibility to draft state zoning enabling act, which was later adapted throughout the United States [3]. G. Nwaka wrote that Nigeria like most other developing nations colonised by the British had its town and country planning ordinance which entails building setbacks from the United Kingdom in 1946 that was later reviewed in 1992 [5]. This regulation is mainly intended to solve developmental problems in emerging cities and urban centres. Bye laws were also drafted by some state governments to handle physical development programmes relating to their locality, a good example is that of Lagos state which was enacted in 1981 Named Town and country Planning (Building Plans) Regulations 1981 [10]. Although meant to serve Lagos state, many states also adapted a similar approach including Niger state.

In the last three decades Suleja had its transformation from a traditional town setting to an emerging city with an influx of population largely because of its proximity to the new Federal Capital Territory which resulted to expansion of its urban landscape in terms of provision of buildings ranging from commercials to residential units. These buildings sprang up in an organic manner without much regulation; this can be attributed to the role of informal sector, since they are the major provider of land and housing in the town. This research work is focussed on studying the problems faced in Suleja as a result of nonadherence to planning regulations especially building set-backs and how it affects the development of the town to a model urban area.

Statement of research question. The rapid expansion in the urban landscape of Suleja as a result of its proximity to the Federal Capital Territory has made it to be one of the fast growing cities in $\mathrm{Ni}$ ger state. Unfortunately the persistence of traditional or informal method of land allocation and development of building without prior building approval from the planning authorities and consideration of building regulations especially building setbacks has continue to prevail in most of the areas of Suleja, this brought difficulty to planning authorities in managing the resultant rapid physical developments in the city, which is becoming a source of degradation in quality of life of the urban dwellers, poor urban growth, and unhealthy built environment. This research paper is geared towards exploring the effects of non-adherence to building setbacks on quality of built environment and city development.

\section{Research methodology}

The study used both primary and secondary data. The primary data were collected directly from field through field survey and oral interviews. The field survey is used to find out building to plot occupancy ratio, light and ventilation of buildings interiors, as well as provision of building plan and approval from Urban planning board, this was conducted in three wards of Suleja these wards include; Bagama, Dawaki and Kurmin Sarki wards respectively, the survey was done on various houses selected at random in different locations within the ward, in which a total of twenty houses were surveyed in each of the three wards; the data collected were analysed using simple frequency. The analysis was used to find out the problems that occur as a result of lack of setbacks and to establish the level inadequate outdoor spaces and natural lightening and ventilation. The secondary data gotten from planning authority was also used to establish level non-compliance with land use regulation. Several literatures from published similar works were also used in the research.

\section{Building setbacks}

Paris. Paris today is rated as one of the word greatest capital worthy of emulation to many, this has not happened over night, the provision and strict adherence of land use regulations which includes setbacks as one of its major constituents dated back to 1867 during the second empire. Earlier than that period the city was regarded as one of the dirtiest and unhealthy place in Europe, growing spontaneously with network of road narrow and twisting streets, inadequate or absence of open spaces, added to unhealthy character of town [8]. But during the philosophical movement of 19th century Paris had a sustainable planning championed by George-Eugene Haussmann which had a forceful impact on the provision of building regulations that includes setbacks meant to ensure safety, better lighting, wide boulevards and healthy built environment. 
Stockholm. Stockholm is the capital city of Sweden and one of the best planned cities in Europe. Relating its historical development [7] wrote that it did not just grow: from the beginning of its modern history, it has been a planned city, the primitive city built mainly of timber suffered eight fire outbreaks within a century, beginning, 1640 and this compelled the rebuilding of the city in a planned and orderly manner under the City Planner known as the 'Conductor'. As early as 1640 , the Master Plan of the area, was adopted and land use regulations that made provision for adequate building setbacks to allow for fire fighting machines adequate setbacks between buildings to allow for outdoor living, lighting and ventilation has improved the quality of the built environment and thereby making the city to what it is today.

In addition this system ensures that plots of land are regularly sized and come in multiples of some basic regular dimensions. Furthermore, the Swedish Building Act, which ensured that all new buildings to be done must be approved by the planning authorities and shall comply with all requirements such as setbacks, building massing, lighting and ventilation.

Nigerian. The history of Land use regulation in Nigeria can be dated back to the pre-colonial era when land was allocated and controlled by the traditional rulers. L. Oduwaye mentioned that prior to colonial administration, before 1854, land-use administration in Nigeria was vested in natural rulers or community heads in different part of the community [6]. They are the Obis, Obas, and Emirs in the east, west, and northern part of the country, respectively. In the case of Suleja they are the Emir and Ward heads (Masu Anguwanni), they had the legal status of trustee beneficiary on land. They had the power to allocate, re-allocate and supervise land use.

In 1946 the promulgation of Nigeria Town and Country Planning Ordinance made Provision for the planning improvement and development of different parts of the country, after independence in 1960 various regional governments in Nigeria retained the 1946 Town and Country Planning Ordinance, Later many states promulgated planning regulations in which Lagos state had their bye law in 1981 named "Lagos State Town and country planning law", this bye law was adopted by many states in Nigeria including Niger state, in which it serves as the major planning regulation in the state till date.
The planning regulation has guided development of building in several sections of Lagos such as Victoria island, Apapa, and several planned part of Lagos, through the provision of good building setbacks that helped those areas in becoming the best planned and healthy areas in Lagos, on the issue of land coverage and ventilation which are also determined by building setbacks, the regulation stipulates that a site coverage of $50 \%$ of the entire plot shall be allowed for in areas of high density and a lower site coverage shall be allowed for medium and high density areas, it also stated that all habitable rooms shall have cross ventilation, . It also make it most to provide at least two car parking spaces per flat or dwelling unit, and that there shall be a motorable road to the site, in this areas the regulation also stipulates that a maximum of twelve flats to be built on an acre is permitted with a boys quarter of two bedrooms per flat, and this condition shall apply to all areas designated low or medium density. The above mentioned regulations made those areas to have a healthy built environment and creates good city image.

\section{Results and Discussion}

Suleja started as a traditional town, with several regulations including guiding principles towards building regulations which includes the land ownership and allocation as well as its usage, this was totally vested on the authority of traditional Chiefs the Emir and Maianguwa (Ward head) respectively, the pattern of the built environment then was organically laid with narrow streets that only offers the buildings access, Building setbacks was less considered, and the was no any regulation concerning it. The consequences were during fire out break several buildings get engulfed by fire, and this was largely as a result of lack of building setbacks. In 1946 the northern region ordinance which include building setbacks was enacted, but less attention was given to it by builders of the time.

In early 1980 the city started experiencing rapid urban growth through the provision of many buildings as a result of influx of relatively lowincome earners from Abuja the new Federal Capital Territory, whom were seeking to solve their problems of accommodation, this was done informally following the same traditional pattern of the town, without proper design consideration, and building setbacks provision, as Many of the developers were greedy to leave any setback 
space in their Land. J. Ahianba, K. Dimuna, G. Okogun wrote that most land developers in Nigerian cities built as much as $70 \%$ of the site, this result to consequences that includes poor setbacks overcrowding and inadequate parking spaces, outdoor sitting, access and ventilation, to the building interior [1]. Despite the presence of planning authority in the town, developers continue to provide buildings with no outdoor spaces, setback interval between buildings as it is clearly evident that most of the buildings done in the town are not issued approval by the planning authority whom ensures that buildings are properly designed before approval.

Provision of building permit. The urban planning development board in Suleja is a statutory body mandated to ensure health safety, welfare and convenience of people in and around buildings, through the use of land use regulations that makes provision of building setbacks, which ensures adequate air space, between buildings, accessibility, density and height of buildings. In other to achieve this, the board mandates land users in Suleja to make application for building permit before commencement of any building; this is done by submission of complete working drawings of the proposed building. In which the requirement of land use regulation is thoroughly checked before approval of building is issued. Table 1 below shows the number of buildings that have building plan and approvals in which only $28.3 \%$ of the buildings surveyed have approved building plans, a greater percentage about $71.7 \%$ does not have building plan nor approved to be erected by the local planning authority which is totally not in conformity to building adoptive bye laws of 1981 .

Table 1: Building Plan approvals

\begin{tabular}{|l|c|c|c|c|c|}
\hline \multirow{2}{*}{ Options } & \multicolumn{2}{|c|}{ Ward Name / Number of buildings } & \multirow{2}{*}{$\begin{array}{c}\text { Total Number of } \\
\text { suildings }\end{array}$} & $\begin{array}{c}\text { Percentage } \\
\text { (\%) }\end{array}$ \\
\cline { 2 - 5 } & Bagama & Dawaki & Kurmin sarki & 17 & 28.3 \\
\hline $\begin{array}{l}\text { Buildings with approved } \\
\text { plan }\end{array}$ & 08 & 05 & 4 & 43 & 71.7 \\
\hline $\begin{array}{l}\text { Buildings without plan and } \\
\text { approval }\end{array}$ & 12 & 15 & 16 & 60 & 100 \\
\hline $\begin{array}{l}\text { Total Number of building } \\
\text { surveyed }\end{array}$ & 20 & 20 & 20 & & \\
\hline
\end{tabular}

Provision of Outdoor Space. The provision of building setbacks along front rear and sides of a building leaves an adequate outdoor space for sitting, parking and adequate lightning. Table 2 above shows the number of buildings surveyed in three wards of Suleja indicating their occupancy ratio to plot area, which determines the amount of outdoor space available within the buildings, a total of 60 buildings were surveyed, 20 in each ward.

Table 2: Building to Plot Area Coverage Ratio

\begin{tabular}{|l|c|c|c|c|r|}
\hline \multirow{2}{*}{ Plot area Coverage (\%) } & \multicolumn{3}{|c|}{ Ward Name } & \multirow{2}{*}{ Total Number of buildings } & \multirow{2}{*}{ Percentage (\%) } \\
\cline { 2 - 5 } & Bagama & Dawaki & Kurmin sarki & & 23.3 \\
\hline $0-50$ & 3 & 5 & 6 & 14 & 30.0 \\
\hline $50-60$ & 9 & 4 & 5 & 28 & 46.7 \\
\hline Above 70 & 8 & 11 & 9 & 60 & 100.0 \\
\hline Total & 20 & 20 & 20 & & 18 \\
\hline
\end{tabular}

The data indicates that $23.3 \%$ representing 14 buildings has a coverage area of $50 \%$ and below, there by having almost equal outdoor space which is in compliance with the building to plot coverage area of $50 \%$ stipulated by the land use, while $(30 \%)$ of the buildings representing 18 buildings had $50-60 \%$ building to plot coverage thereby has $40 \%$ outdoor space, and finally $46.7 \%$ had more than $60 \%$ building to plot coverage thereby has less than 40 , which is totally non-compliant with the land use regulation. 
Lighting and Ventilation. Achieving Lighting and Ventilation is one of the major criteria in design that determines both visual and thermal comfort of building occupants, it also one of the criteria for building approval where the bye law addresses the issue of ventilation by stating that all habitable rooms shall have cross ventilation, and this can only be achieved through the provision of at least two windows on two different walls of a room. Table 3 below shows the number of buildings survey in three wards of Suleja indicating the total number of windows on the surveyed buildings, each ward comprising of 20 buildings.

Table 3: Number of windows per room

\begin{tabular}{|l|c|c|c|c|c|}
\hline \multirow{2}{*}{ Number of windows } & \multicolumn{2}{|c|}{ Ward Name/ Number of room } & \multirow{2}{*}{ Total Number of Windows } & \multirow{2}{*}{ Percentage (\%) } \\
\cline { 2 - 5 } & Bagama & Dawaki & Kurmin sarki & & 25.3 \\
\hline Two and above & 18 & 16 & 22 & 150 & 68.0 \\
\hline Only one & 61 & 43 & 46 & 15 & 6.7 \\
\hline None & 8 & 04 & 03 & 221 & 100.0 \\
\hline Total & 77 & 64 & 71 & & \\
\hline
\end{tabular}

The data indicates that $25.3 \%$ of the habitable rooms have adequate cross ventilation and lightning whilst $68 \%$ of the habitable rooms has only one window. On the other hand, $6.7 \%$ of the habitable rooms has no windows.

Discussion of Findings. The result of this research shows that large numbers of buildings in Suleja were built without setbacks adherence, this indicates the level of greediness on the side of developers whom build almost all portion of their plot without setbacks, and this leads to an urban decay, the study showed that only $28.3 \%$ of the buildings in the town had been approved by the local authority, the remaining $71.7 \%$ were unplanned buildings, this confirms the statement of G. Nwaka who mentioned that only about 20$40 \%$ of physical development in Nigerian cities were carried out with government formal approval [6]. However, this has led to irregular settlements which had become so pervasive having little or no setbacks, Figure 1 below shows a closely spaced buildings with no setbacks in Bagama ward of Suleja, in case of fire outbreak there will be no access for fire fighting Machines around any of the buildings and it is easily for the fire to spread to the next building and in case of collapse it will still affect the other one.

A spacious arrangement of buildings with good setbacks helps in the provision of a good visual perception both indoor and outdoor and create a level of comfort for the inhabitants of the built environment, through the gain of natural light and ventilation Figure 2 illustrates how well spaced buildings with good setbacks can have access to natural direct light and ventilation, devoid of obstruction by the neighbouring building.

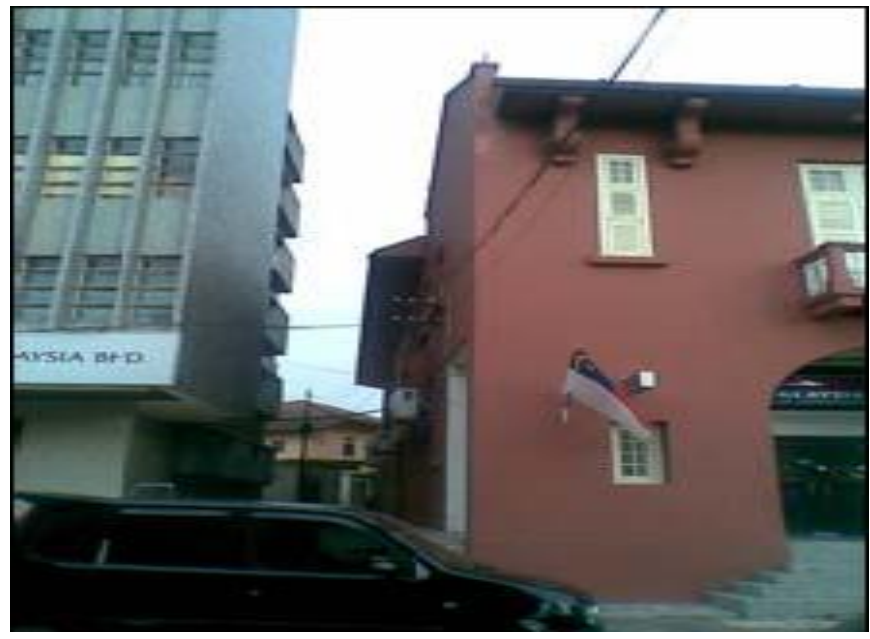

Figure 1 - A closely spaced building without setbacks

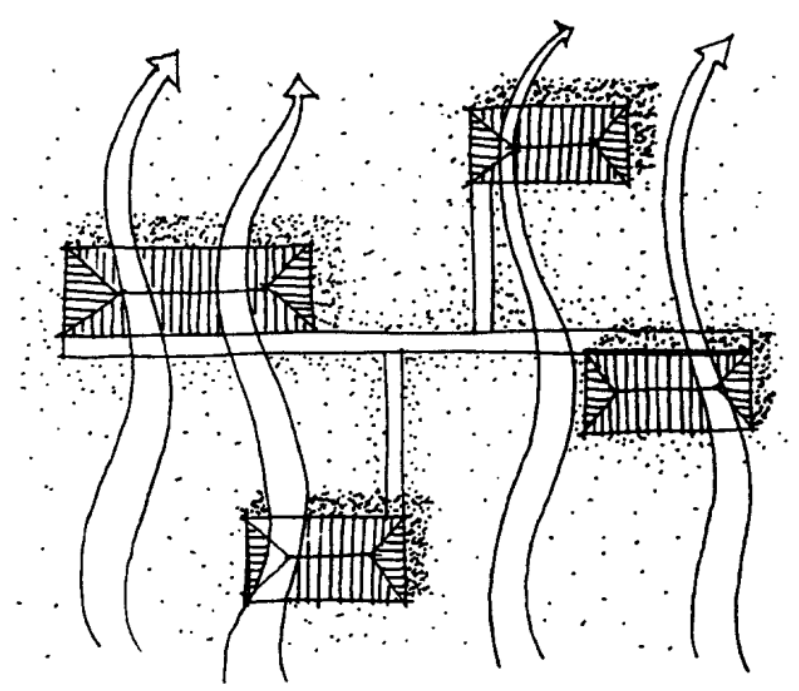

Figure 2 - Adequate Building Setbacks, with proper ventilation and Lightening [4] 
The spaces left for as setbacks can be used for the creation of aesthetics value and beautification in a building environment. A well landscaped setback spaces can improve the Architecture of the environment through visual and psychological perception of the occupant of a building as written by J. Ahianba, K. Dimuna, G. Okogun that landscaped environment pleasures and relax a troublesome heart and aids longevity [1]. Figure 3 below shows how landscaped setback spaces add beauty to an environment, it also helps in cooling the microclimatic condition of the environment through shading and evaporation.

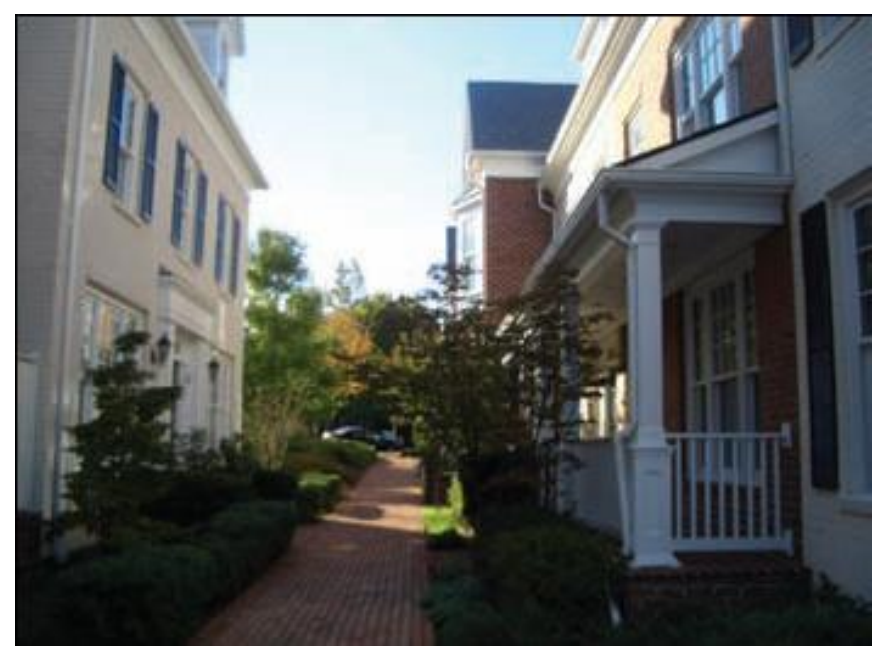

Figure 3 - A well landscaped setback spaces [2]

Z. Samadi and M. Hasbullah wrote that the overall perceptions on the city atmosphere on indoor and outdoor views of spaces are subject to the end users' personal judgment [9]. Then, end users will decide to accept or to reject the quality of the city, and individual perception may lead to the communal perception and hence the communal perception may lead to the overall image and identity of the city. The consequences of nonprovision of setbacks in buildings are already manifesting and are being felt in Suleja. The deterioration of the built environment has serious health effects to city dwellers, including traffic injury and death and it undermines the civic pride. The decay can get worse if unchecked. It can also be dangerous in case of fire outbreak; it is difficult for fire vehicles and men to gain easy access to the building, as well as overcrowding and inadequate parking spaces.

The survey conducted reveals that there are few buildings that has outdoor spaces as a result of setbacks provision, as only $23.3 \%$ of the build- ings in Suleja had adequate setbacks that made them to have outdoor spaces, as against the land use requirement which stipulates site coverage of $50 \%$ for residential buildings in high density areas, and $33 \%$ for low density areas, the remaining $76.7 \%$ fall short of the requirement, developers were so greedy and they built as much as $70 \%$ or more of the site.

On the issue of lightening and ventilation only $(25.3 \%)$ of the habitable rooms surveyed in (60) buildings units of the three wards of the town has windows on two different walls of the rooms, while (68\%) forming bulk of the survey has only one window and this offers less or no cross ventilation and this is mainly done because there is no setbacks on the sides of the buildings thus the building is so closed to another one or road that does not warrant means to provide window, J. Ahianba, K. Dimuna, G. Okogun wrote that Lack of ventilation in buildings encourages high humidity level that favours the breeding of various kinds of fungi that contaminate food items, furthermore, the breathing in the air in such buildings does cause cold, catarrh and breathing, problems among the old people and asthmatic patients [1].

\section{Conclusion}

For any emerging city to grow into a healthy and functional built environment, building regulations has an important role to play, the paper has shown how building setbacks influences the growth of some leading cities in the world, like Paris which was not a planned city but until 1867 during the second empire. Building setbacks has made the city to have wide boulevards and adequate outdoor spaces, while in Stockholm which was guided by building regulations since 1640 achieved in the betterment of her built environment from windy narrow streets and congested buildings to a spacious and healthy living environment through provision of building setbacks.

The research revealed that most of the buildings in Suleja were haphazardly placed following the traditional pattern and it results to several problems that includes; Lack of outdoor spaces for parking, children play, and Landscaping, Unsafe Built Environment in case of fire outbreak, for lack of access to fire fighting Machines and quick spread of fire to neighbouring buildings, as well as during demolition or collapse the neighbouring building will be affected too, Lack of visual 
perception of aesthetic, Poorly lightened and ventilated interiors, with little or no consideration to building setbacks, has largely leads to a poor city growth, as the survey of some selected building units shows that less than $25 \%$ of the buildings were in conformity to the stipulated land use regulations that includes setbacks, this has a serious threat to the health and safety of the occupant of the built environment. Finally the study found out that as a result of the above mentioned problems, the visual perception of the city is weakened thereby creating a poor city image in the minds of many people.

\section{References}

1. Ahianba, J. E., Dimuna, K. O., \& Okogun, G. R. A. (2008). Built Environment Decay and Urban Health in Nigeria. Journal for Human Ecology and Management, 23(3), 259-265.

2. City of Chesapeake, Virginia. (2007, August 28). Design Guidelines for the City of Chesapeake.

Retrieved from http://www.cityofchesapeake.net/government/City-

Departments/Departments/Planning-Department/Planning-Library/plans_studies/designguidelines.htm

3. Fisher, J. (2006). The Basis of Building Setbacks and \% Lot Coverage. Retrieved from https://goo.gl/m9Y12Q.

4. Gallo, C., Sala, M., \& Sayigh, A. M. M. (1998). Architecture Comfort and Energy. Oxford: Elsevier.

5. Nwaka, G. I. (2005). The Urban Informal Sector in Nigeria: Towards Economic Development, Environmental Health, and Social Harmony. Global Urban Development Magazine, 1(1), 1-11.

6. Oduwaye, L. (2006). Citizenship Participation in Environmental Planning and Management in Nigeria: Suggestions. Journal for Human Ecology, 20(1), 43-48.

7. Oko, J. O. (2010, September). Sustainable design, planning and policy considerations for the prevention of slum in emerging cities and megacities. Paper presented at the Archibuilt Forum 2010, Abuja, Nigeria.

8. Pasold, L. (2012, February 6). Paris Buildings: A Brief History. Retrieved from https://parispropertygroup.com/blog/2012/paris-buildings-a-brief-history

9. Samadi, Z. H. Hasbullah, M. N. (2008). The enhancement of spaces in between buildings as urban recreation development. In ECER Regional Conference Paper (pp. 1-13). Retrieved from https://www.academia.edu/781829/Enchancement_of_Space_in_Between_Buildings_for_Urban _Recreation_Development

10. Town and Country Planning Law (Nigeria, Lagos). Retrieved May 10, 2017, from http://www.lawnigeria.com/LawsoftheFederation/NIGERIAN-URBAN-AND-REGIONALPLANNING-ACT.html 